\title{
The constitution of objectivities in consciousness in ideas I and ideas II
}

\author{
A constituição de objetividades na consciência em
}

Ideias I e Ideias II

Nathalie Barbosa de LA CADENA ${ }^{a}$

\begin{abstract}
In this paper, I present the difficulty in the phenomenology of explaining the constitution of objectivities in consciousness. In the context of phenomenological reduction, constitution has to be understood as unveiling the universal and necessary essences. Recognized by Husserl in Ideas I and named as functional problems, the constitution of objectivities refers at first to individual consciousness, and then to an intersubjective one. In Ideas II, the phenomenologist explains how the constitution of nature, psyche, and spirit occurs. This process begins by assuming three premises: the ontological realism, the regularity of nature, and the transcendental idealism. In this process, the ego, apart from constituting objects (the body, the psyche, and the others), constitutes itself. The objects of material reality are constituted through aesthetic synthesis which unifies singularities and contextualizes the lived experience. The body, as a perceptive organ, perceives the exterior, and the location of the sensory stimulus is the soul. The soul is a real and transcendent object, which is linked to physical things that are constituted in a solipsistic way or intersubjectively. Empathy allows the subject to recognize the consciousness of the alter ego as capable of spontaneous movements and actions, a copresence sharing the same horizons. Thus, through the theoretical attitude, the physical world is perceived, and through the spiritual attitude the spiritual world is perceived, a living world shared by free intelligent beings. For this, intersubjectivity fulfills a fundamental role, because only in the relationship with the other does the identity of the objects, of the other, and of the self become evident.
\end{abstract}

Keywords: Husserl. Constitution. Intersubjectivity.

\footnotetext{
a Universidade Federal de Juiz de Fora (UFJF), Minas Gerais, MG, Brasil. Doutora em Direito e Filosofia, e-mail: nbcadena@gmail.com
} 


\section{Resumo}

Neste artigo, apresento a dificuldade da fenomenologia em explicar a constituição de objetividades. No contexto da redução fenomenológica, constituição deve ser entendida como desvelamento das essências universais e necessárias. Reconhecido por Husserl em Ideias I e chamado de problemas funcionais, a constituição de objetividades se refere primeiramente à consciência individual, e depois, à intersubjetiva. Em Ideias II, o fenomenólogo explica como a constituição da natureza, psique e espírito ocorre. Este processo começa assumindo três premissas: o realismo ontológico, a regularidade da natureza e o idealismo transcendental. Neste processo, o ego, além de constituir objetos (o corpo, a psique, e os outros), constitui a si mesmo. Os objetos da realidade material são constituídos através da síntese estética que unifica singularidades e contextualiza as vivências. O corpo, como órgão perceptivo, percebe o exterior, e o local do estímulo sensorial é a alma. A alma é um objeto real e transcendental, que está ligado a coisas físicas as quais são constituídas de modo solipsista ou intersubjetivo. A empatia permite aos sujeitos reconhecer a consciência do alter ego como capaz de movimentos espontâneos e ações, uma co-presença compartilhando os mesmos horizontes. Portanto, através da atitude teorética, o mundo físico é percebido, e através da atitude espiritual, o mundo espiritual é percebido, um mundo compartilhado por seres livres e inteligentes. Sendo assim, a intersubjetividade tem um papel fundamental, pois somente no relacionamento com os outros, a identidade dos objetos, dos outros e do eu torna-se evidente.

Palavras-chave: Husserl. Constituição. Intersubjetividade.

The constitution of objectivities in consciousness is a challenge to the transcendental phenomenology recognized by Husserl in Ideas I; what he calls Die funktionellen Probleme (HUA III, 176). In Ideas II, he confronts this question in a more detailed way in order to explain how the correlation occurs between consciousness and the different kinds of objectivities available in the world, that is to say, how the objective units of different ontological regions or categories are consciously constituted, and how all the bonds of effective and possible consciousness are prescribed by the essence of these objective units as possibilities of essence.

In Ideas I, Husserl presents and recognizes this difficulty of phenomenology by emphasizing its transcendental dimension, that is, it defines consciousness as the place of knowledge, unveiling or constitution of the world (HUA I, 115-116), and states that this world is an objectivity independent of subjectivity (HUA III, 11, 17, 
49, 70, 74, 84, 86-87, 98-103; HUA I, 57, 65, 95, 123) its understanding being possible through the unveiling of the a priori essences.

In Ideas II, Husserl no longer discusses his premises, transcendental idealism and ontological realism, he turns to the world to know it, starting from the cogito as a unit belonging to this world, human existence as transcendent, as operant life. This will be the emphasis of this article.

\section{Ideas I}

In order to understand the functional problem of "Konstitution der Bewußtfeinsgegenftändlichkeiten" (HUA III, 176), first we must define the term 'constitution'. Husserl, in the context of the phenomenological attitude, must explain how the philosopher manages to make objects evident, how the syntheses exhibit these lived objective units. 'Constitution' is, for Husserl, unveiling. It cannot be understood with 'creative' nuances, as Crespo (2009, p. 106) emphasizes. It cannot be confused with the Kantian attitude of legislating over the world with the transcendental categories. The subject of knowledge in Husserl imposes nothing on the world. On the contrary, he is in a state of epoché, with his judgment and expectations suspended; knowledge and categories are in parentheses. That is why it is so important to understand this term in the light of its context.

To constitute is also to give meaning. However, 'giving meaning' should not be understood as consciousness creating a sense for an objectivity. Real and ideal effectivities are represented by the multiplicities of meanings and propositions corresponding to them, limited by their essences (HUA III, 279). Each thing in nature is represented by all the senses and variable propositions, that is to say, it is represented by the multiplicities of full nuclei in which it can be noematically constituted as something identical.

This constitution refers first to an individual consciousness and then to a common intersubjective consciousness for which a single thing can be given and identified intersubjectively as the same objective effective thing.

Therefore, an object determined by the regional class has its modes of being prescribed a priori, has its conditions of being perceived, represented in a clear or obscure way, thought and attested (HUA III, 310-312). In other words, the material 
universality of the regional and categorical essence manifests itself, for each region offers the thread for its own closed group of inquiry.

In the lived experience (Erlebnis) we grasp, in ideation, the essence of the thing as subject of delimited general noematic determinations. Husserl starts from the experience of a material thing. The essence 'thing' is given originally, but this data is not adequate by principle. For an adequate eidetic apprehension, the eidetic variation is operated. The region 'thing' given inadequately prescribes rules for the progress of possible intuitions. Ideal possibilities are part of the essence of a noema of thing, from which coherent intuitions proceed without limit according to prescribed directions. The process has no end, but that does not mean it is random.

In this sense de Oliveira mentions the example of the constitution of a tennis ball: "As opposed to sensuous seeing in the natural sphere of cognition, "immediate seeing" is no longer reduced to the perceptual mediation of "natural experience" but appears as "pure essence" (Eidos), which in fact makes empirical seeing possible" (2000, p. 261)

Therefore, the epistemological order cannot be confused with the ontological order. In the epistemological order, we first have the experience of objectivity simultaneously with the intuition of its essence, apprehended inadequately, but it is sufficient to direct the next stage of understanding and description of the essence. In the ontological order, the essence is a priori, universal and necessary, is transcendent, is in the world, is not a transcendental synthetic judgment a priori with which one legislates over the world. The essence is a condition of possibility of the lived experience.

Thus, from the determined directions, we unveil the idea submerged in an infinity of variables. The regional idea of the thing in general is grasped as an idea of the identical that is conserved. Ideas understood as eidetic needs contained in the noema and in the given consciousness that can be clearly understood and systematically investigated. Ideas as res temporalis, res extensa and res materialis are essences of material thing.

The series of apparitions belonging to the unity of an appearance can be intuitively achieved by the looking and can be theoretically apprehended, can be analyzed and described in their eidetic peculiarity, and the operation which establishes by law the correlation between the determinate thing which appears as unity and the 
infinite determinate diversities of apparitions can be seen in all its evidence. Therefore, the idea of the actual thing represented in pure phenomenological consciousness is an absolutely necessary correlate of a noetic-noematic nexus investigated in its structure and described in essence, is universal and necessary, it is a priori.

At this first level, the constitution takes place in the individual dimension of empirical consciousness. The next higher level is the constitution of the thing as intersubjectively identical. The intersubjective world is the correlate of experience mediated by empathy (Einfühlung). Empathy plays a constituent role in "objective" experience and gives unity to the dispersed multiplicity (HUA III, 317).

The example offered of constitution of the material thing and system of multiplicities of experience encountered before all "thinking" has to be transferred to all regions of object. However, other objects will present rather difficult problems such as the interweaving of various ontological spheres. Moreover, the thing is not isolated before the empirical subject, its constitution is intersubjective. Just as the empirical subject itself is constituted as real in its lived experience, as human or animal, as well as the intersubjective communities. Although founded in psychic realities, in physical realities, these communities are new objectivities of a higher order (HUA III, 319).

It is from this point that Husserl starts off to write Ideas II. In Ideas I, Husserl departs from the pure self. His description is transcendental. It is the application of the phenomenological method for the description of essences intuited in the lived experience. Constitution as the unveiling of universal and necessary essences, a priori, independent of subjectivity, given at first inadequately, but which direct the eidetic variation and allow its intersubjective constitution.

\section{Ideas II}

In Ideas II, Husserl traces the history of how, from the self, an ambiguous reality, subject and object of the world, is constituted: human existence, transcendent, as operant life. In this work, Husserl applies the phenomenological method, but this time turns to description of the transcendent sphere. The theme is the constitution of reality in pure consciousness: nature, animal world, spirit. The unveiling of the being of existence, being of the world, sense of the world is derived from unveiling of life. 
The work is divided into three parts that correspond to strata of being such as transcendent realities, nature, animal world and spirit. Which part is known from two attitudes, the theoretical or naturalistic attitude, and the spiritual or personalistic attitude, also called practical-evaluative. Along with the process of constitution, or unveiling of the being of existence, or even, of explicitness of the being of the world, the self is also explicated. That is to say, in constituting the world, consciousness constitutes itself. The pure self recognizes itself as an entity of the world, but at the same time as a subject for which the world is revealed. Thus, the pure self abandons its condition of being in the world and awakens as a spiritual being, a being that lives and is constituted intersubjectively.

\section{The objects}

Husserl begins by offering a definition of nature as the field of transcendent realities, or the space-time orb in its totality, the total domain of possible experience. His initial object of investigation are those objects given to the senses, typical of the natural sciences, whose criterion of truth is correspondence (HUA IV, 2-3).

In this case, the attitude is to intuit and think in a scientific-natural way and, in a phenomenological description of this attitude, it is possible to identify the noese, the thematic attitude of experience as scientific investigation, and the noema, nature as an intentional correlate of experience. In this attitude, the subject of knowledge seeks patterns, regularities, repeats, tries to list and control variables, measure. It is a theoretical attitude, but not limited to a set of doxic acts, it is an active attitude towards an end (HUA IV, 3-4).

The first step is to identify how experience is performed in terms of knowledge, for having the thing in the field of perception is different from being clear about something, becoming aware of the thing, being actively directed, executing a judgment toward to an end.

Doxic lived experiences in this attitude, in this manner of explicit performance (I think, I perform an act in the specific sense, I posit the subject and thereupon posit the predicate, etc.) we term theoretical acts. In them, not only is an object simply there for the Ego, but rather the Ego is, as Ego, thereupon direct attentively (and then comes thinking, active positing), and thus it is at once directed to the object in a grasping way: as "theoretical," it is, in an actual sense, Objectifying (HUA IV, 4). 
The theoretical attitude may direct the investigation into an individual view or a categorical view, both performed by higher level acts. (HUA IV, 6) The categorical objectivities constituted by the preceding theoretical acts are pre-given, that is, the objects of the theoretical attitude are already pre-constituted. What changes is the attitude, the aim, the intention, the end, but the object is already there. This is because every act admits a transition to the theoretical attitude, for example, it is possible to convert an emotive, practical or volitional act into a theoretical act. Thus, observing the object in a theoretical attitude, it is possible to find the objective stratum of those acts (HUA IV, 14).

In the case of objects of material reality, the thing is constituted through aesthetic synthesis. The aesthetic synthesis fulfills the role of unifying the singularities, unifying the objectivities constituted by different sensorial spheres and contextualizing the lived experience. I explain: objects can be constituted by multiple theses, however, they are singular objects; they have their unity. This unity contains partial mentions and may consist of different sensory spheres, for example, vision and touch, aesthetic synthesis, although partial, unify the objectivities (HUA IV, 19-21). In addition, nature as a correlate of modern science, as a sphere of mere things and objectivities, offers the context of this experience. In the natural sciences, the researcher assumes a purely theoretical attitude, away from emotions, but values logical judgments, abstracting all other values, except the values of knowledge. Thus the natural sciences dissociate themselves from other spheres of objects which can also be treated theoretically (HUA IV, 25-26).

In this way it is possible to consider the thing in isolation or the thing in its circumstances. Taken in isolation, its first note is extension, an essential attribute of its materiality (HUA IV, 30). Besides extension, still considering it in isolation, it is possible to reveal "sensuous schema" (HUA IV, 37), accidental qualities or phantoms that lack a permanent background.

Considering the thing and its circumstances, what is sought is its reality (Realität), a set of qualities that remain unchanged, that endure even when subjected to variations. Considering the thing and its circumstances, the first dimension is substance, that is, what remains against the variations, the second dimension is 
causality, that is, the interdependence between the variations of the thing and the variations of the circumstances. Substance and causality make up the reality of the thing, its unity, unity in plurality.

Causality supposes the permanence of the bodily conditions of perception, that is, while these remain, any variation in the object can be referred to. Therefore, the physical thing perceived depends on the corporeality. It is an individual constitution of objectivity. So that the body functions as an intermediary between subject and object.

Let us see how it works: In the essence of material things in principle are the possibilities of rest and motion, change and permanence. Every sensible thing requires in its givenness, as a basic fragment of its essence, a full spatial body. Considering the extensive and qualitative changes, we observe that, in the perception of cosmic changes, the essence reaches us in the real perception as continuous courses of sensible schemes.

\footnotetext{
But here it must be observed that rest and motion, change and permanence, get their sense by means of the constitution of thinghood as reality, in which such occurrences, especially the limit cases of rest and permanence, play an essential role (HUA IV, 62).

The thing is what it is in its thingly nexus and "in reference" to the experiencing subject, but it is still the same in all changes of state and of appearance it undergoes as a consequence of the altering circumstances. And as the same thing it has a stock of "lasting" properties (HUA IV, 76).
}

Therefore, the thing is what it is in reference to its circumstances. Functional nexuses that refer to possible schematic modifications, that is, permanence is the limiting case of change. There are permanent material properties, such as color, elasticity, solidity, liquidity among others; and there are permanent determinations of the extension, position and figure. These are possible permanences that resist even in the face of change. Permanences determine, limit, and direct the possibilities of change, and changes are causal dependencies (HUA IV, 42).

The constitution of a unit goes through all the changes. There is a unit in the changes of properties and a unit in the series of changes. However, the properties can be modified in a certain way depending on the circumstances, so that through property changes it is possible to move to a new unit. For example, $\mathrm{H}_{2} \mathrm{O}$ may be in a solid, liquid or gaseous state depending on the circumstances, however, at least one property remains unchanged. 
The premises that Husserl assumes, so that the knowledge of nature and of natural things is possible, are evident. First, ontological realism, that the world exists independently of subjectivity, is given, is the same for any subjectivity. Second, the regularity of nature is given, that natural sciences are only possible by assuming the premise that nature functions in a regular and orderly manner, that there is something constant and invariable both in objects and in their relations that allows the apprehension of variations. Third, transcendental idealism is given, that the whole process of knowledge takes place in consciousness, in an active cognitive subject capable of theoretical acts and also of judgment directed towards an end. (HUA IV, 14-15).

At this point, the body is a condition for constitution of the object, for it is through the body that the intuition and the constitution of nature in consciousness are possible and, later, an understanding of its real and invariable dimension. The body is the instrument that allows the relation between the cognoscent subject and nature, the world and things. Then, in establishing this relation before all variations, the identical in all appear, having the physical thing.

Even in this pre-givenness sphere, the body is not constituted as an object, but only as a condition of the constitution of the objective.

\section{The body}

The constitution of the objective material thing refers to a subject who through aesthetic synthesis unifies the continuous multiplicity of sensible intuitions. This is the thing for a singular subject, referred to the body and the normal sensibility; the thing constituted for an isolated and self-forgetful subject.

Considering only this first moment, when the subject is still isolated, the body is only a set of conditions of perception. An instrument through which basically two kinds of sensations are possible: sensations constituting the notes of the thing, for example, colors, and sensations of circumstances, for example, if-then, motivated by real and possible, transcends, in addition to those circumstances with periodic and unchanged variations. Therefore, thanks to the courses of perception, there is before me one and the same external world (HUA IV, 58). 
Things are experienced, they are intuitively given to the subject, necessarily as a unit of a causal-space-temporal nexus, and to this nexus necessarily belongs my body, as the essential place and necessity for whom the world reveals itself, a system of subjective conditionality interlaced with a system of causality (HUA IV, 64-65).

Now the body is considered as a field of sensibility, a place where the sensations spread and articulate. They are, in fact, two moments of the same event. The body is the inner face of the perceived outer world. Husserl uses two words to distinguish these two moments: Körper and Leib, both translated as body. Körper is the body as a thing, and Leib is the body as a perceptive organ.

A tactile example contributes to understanding: by resting my hand on the table, I perceive the quality of the table and the sensation in my hand, the stimulus occurs in two steps, a sensitive (tactile) perception of the appearance of the thing and the psychic impression located in the percipient organ. The corporeal organ perceives the exterior, and the location of the sensitive stimulus is the soul. In this process, the transcendental self will constitute itself in opposition to the "object", as Tourinho (2016, p. 92) explains. Husserl distinguishes material Ausdehnung, a material expansion of the sensitive stimulus, and Ausbreitung of the soul, sensory propagation of the sensitive stimulus.

The body is therefore the field where the psychic phenomena are exteriorized and ordered, it is an organ of the will since it is the only reality that can be moved by the subject, and a center of orientation, the referential here of the subject.

\section{The psychic}

Still in a theoretical attitude, the nature of material objects is constituted, whether of a psychic, human or animal nature. Husserl proposes a scientific-natural investigation of the soul essence in its attachment to the material body. However, he makes clear that the givenness of the soul is not given by the bond with the body, but it is a stream of lived experiences (or stream of consciousness), something with its own essence.

In self-perception, each human being captures himself, his actions and states, his personal qualities and attributes, predispositions of character and abilities (HUA $I V, 93)$. The self is a referential point for the lived experiences, is origin and place, in 
the self is understood the whole being with soul and body. However, psychic has an advantage:

[...] it is easy to see that the psychic has a priority and that it is what determines the concept of the Ego essentially. When the soul departs, then what remains is dead matter, a sheer material thing, which no longer possesses in itself anything of the man (HUA IV, 94).

The soul is a real and transcendent object, which animates the body, is linked to physical things forming with the body a unity. The soul is the substrate of the psychic properties, different from the thing, has a history, is part of the higher sphere, is able to determine itself, and invites ascension to the spirit.

The perception of self with abstraction of the body directs the ray of attention of the self, to the origin of the acts. What, or who, is this source from which emanate acts of the most varied species? Self-perception is possible because the pure self can differentiate itself from the acts as it executes them and refers to objects through them; on the other hand, it can only be differentiated abstractly (HUA IV, 99).

I realize, I feel, I want, I judge, I think. The cogito captures by reflection the self, captures the pure subject. It is of the essence of the pure self to grasp itself as what it is while it performs its function and can thus be considered as an object (HUA IV, 101).

In self-perception, the thinking self is distinguished from the thought self, but both are one and the same self. The thinking self in thinking about itself, as the subjective pole of lived experiences, changes from pure subject and becomes an object of a new act of consciousness, but this act is an act of the same self, and thus captures the thought self as identical with the thinking self only in its previous moment. Thus, self-perception captures the self as unity in duration. The acts of consciousness change, but the consciousness remains the same, the center from which the acts radiate and to which all the stimuli arrive. The subject is variable in his actions, but invariable in himself.

[...] the pure Ego is given in absolute selfhood and in a unity which does nor present itself by way of adumbrations; it ca be grasped adequately in the reflexive shift of focus that goes back to it as a center of functioning. As pure Ego it does not harbor any hidden inner richness; it is absolutely simple and it lies there absolutely clear. All richness lies in the cogito and in the mode of the function which can be adequately grasped therein (HUA IV, 105). 
The subject is intentionality, an absolutely simple self, a life in acts. The subject is active, assumes attitudes, persists in positions, has a style and a way, takes a free posture before the world. Husserl states "we are, however, free intelligent beings" (HUA IV, 89). Habits are not objective content, but permanent properties of the self, repeated decisions, convictions, and attitudes of existence, faith and love.

In this way, the subject becomes concrete. The transcendental self looks at itself and does not see hypotheses, categories or forms, but attitudes, actions, postures, works, active life. Its concreteness is revealed in pure subjectivity, above mundane, but as lived life, with its way of being, way of acting, and own style.

\section{Intersubjectivity}

So far, the constitution of reality has occurred in isolation, in an individuality. However, the constitution of body-soul reality is only completed at the intersubjective level. Assuming a new evaluative and practical attitude, a spiritual attitude.

The world is constituted intersubjectively and constantly accredited thanks to the concordant exchange of experiences. Everything of my experience belongs to my surroundings, and this means that my body is also there, as a body in the world. The apprehension of the body plays a particular role for intersubjectivity, for all objects are apprehended objectively through the body, as thing in a unique objective time, in a unique objective space of a unique world.

The thing that is constituted for the singular subject acquires a character of mere subjective appearance of the thing of the objective reality; each of the subjects who understand themselves intersubjectively about the same world, and about the same thing, have this same thing in their perceptions, and in them their unity of appearance, which is the same apparition, only in a higher sense, with predicates of true apparent thing. The true thing is now the object which in the multiplicities of apparitions of a multiplicity of subjects remains identically firm. Therefore, the physical thing is constituted in a solipsistic way or intersubjectively, that is to say, what a cognoscente subject knows in logical objectivity every knowing subject can also know, it is enough to fulfill the conditions that have to satisfy all cognoscente beings of such objects (HUA IV, 82). 
Reasoning is similar when the object of apprehension is the other. The other is perceived, initially, as a body along with things and, alongside this perception, there is an apperception of the co-given horizons. Perception corresponds to the original presence (Urpräsenz), and apperception corresponds to co-presence (Appräsenz). I immediately grasp his body and simultaneously a co-present horizon of meanings, a shared horizon (HUA IV, 162-163).

There is an identity between the body of others and mine, it is an analogical presentation, a moment of empathy, the moment of the encounter between the self and the other involves the recognition of the other subject as an animated organism endowed with bodily movements, expressions, gestures, speech, will. In this sense, Luo (2016, p. 7) considers that "embodiment and empathy are closely interrelated, not only because the lived body serves as a basis for the constitutional analysis of the other, but also because the bodily similarity between oneself and the other is the motivating factor that brings concrete empathic experience into play." "The correspondence between the ego and the alter ego is made by analogy. It is the recognition of the consciousness of the alter ego as capable of governing movements and actions spontaneously. I understand my body and your body, here and there, there is a co-presence in common horizons. (HUA, IV, 198)

In Husserl's words:

\begin{abstract}
The strata of the constitution of nature which have been exhibited teach us how this apprehension is to be evaluated: at the lowest level there is constituted, in the manner previously described, the intuitive material world and, correlative to that, the experiencing subject, one that has Body and soul but is not yet the real unity "man," is not yet an Object in nature. Then there are constituted the other subjects, apperceived as analogons of oneself and, at the same time, as natural Objects; nature is constituted as intersubjectivity common and as determinable Objectively (exactly), and oneself as subject is constituted as member of this "Objective nature" (HUA IV, 170/171).
\end{abstract}

At this moment, the other is a physical reality, a point in space. The other person's gaze objectifies the soul subject, the soul of the other is a thing between things, it is a mere substrate of real events in the body, sensations and emotions. Here is the theoretical attitude that naturalizes the other, important for the realization of the natural sciences.

Husserl assumes, then, the spiritualistic attitude in search of foundation for the sciences of the spirit. In a naturalistic (theoretical) attitude, the soul is nothing more than an epiphenomenon. On the other hand, a transcendental (spiritualistic) attitude 
returns to the origin, to the pure self, to the original character of the intentional consciousness.

The subject is the center of the world, alive and responsible. The world is world to me. The world is formed by reference points of my practical needs and valuation appreciations, things are useful and their meaning is inseparable from my practical intention, always suitable to ends.

\begin{abstract}
That is an overview of the field of proper Egological facts. The Ego is always a subject of intentionalities, and that means that a noema and a noematic Object are immanently constituted ("apperception"); consciousness of an Object is produced. In particular, an Object posited as existing, which is present to consciousness in its "how," enters into an "intentional" relation with the subject in a new sense: the subject comports itself toward the Object, and the Object stimulates or motivates the subject. The subject is subject of an undergoing or of a being-active, is passive or active in relation to the Objects present to it noematically, and correlatively we have "effects" in the subject emanating from the Objects. The Object "intrudes on the subject" and exercises stimulation on it (theoretical, aesthetic, practical stimulation) (HUA IV, 219).
\end{abstract}

Thus, everything returns to the heart of intentionality. Husserl emphasizes the world of existence as prior to the constitution of the world of nature. In other words, the world of natural science is derived because it comes from of a reduction of the world around (Umwelt). That is to say, the world constituted from a naturalistic attitude is not the world, because the everyday world of the spiritualistic attitude precedes it, the notion of living world (Lebenswelt).

In this sense Zahavi (2001, p. 61) explains:

\begin{abstract}
On the basis of these discussions, however, we can immediately make fruitful use of our earlier distinction between two types of relation to others: one type is the a posteriori and presumptive character of our currently actual experience of others, while the a priori and apodictic character of open intersubjectivity is something else entirely. As Husserl writes, the explication of my own transcendental present horizon leads to transcendental and currently actually co-present others and to their horizons, and it becomes clear on this basis that there is an apodictic universal structure of intersubjectivity predelineated in every ego whatsoever (15/192).
\end{abstract}

The cognoscent subject is not only a man present in the world, but a person, a spiritual subject, and the law governing this relationship is not causation but motivation (HUA IV , 228-235). The objects are stimuli for action in a dual intentional, passive and active reference. Passive as reception of the sensory stimulus, active as the reaction of the self directed to an end. The self as the unit, source of the conscious act of theoretical judgment, opens up a range of possibilities, actions, and reactions, governed by freedom. Therefore, we have as essential mark of the person the 
intelligence, a subject capable of judgments, and freedom, a subject capable of performing actions (or omissions) according to his judgment.

Now the perception of the other is not only his body and soul, but the apperception that something is realized through the body, something that gives a unity to the natural thing, a joint of meaning, the spirit. In addition, the apperception is not only from the experience of the body of others, but also from their works, cultural achievements, such as books, art, music, etc. each of these achievements is accompanied by an expressive meaning, as well as a physical thing also permeated by a spiritual sense.

This act of awareness, empathy, realizes the interpersonal world (HUA IV, 198), allows the understanding of what is expressed in the spiritual realizations, reveals the free motivations and actions. Here the constituted is not only an objective thing, but, through a spiritualist attitude, it constitutes a community of spiritual subjects.

There are two classes of realizations occurring simultaneously. Through the theoretical (naturalistic) attitude the physical world and its objects are perceived, through the spiritual (personalistic) attitude the spiritual world and its senses are perceived. The former is governed by causality, the latter by the motivation that constitutes sociability, a community of meanings shared between me and the other through communicative acts. Thus, is constituted the spiritual world, an objective world of a higher level shared by people.

It is the person in his concrete life, active, giving meaning, who makes decisions, has convictions and exercises his freedom. The person needs this base that is the world around, it is constituted in reference to it. On the other hand, it is he who gives it meaning, the world is world to me, it is the pure self in its concrete life, no longer monad, but person. In other words, the person is the result of this interaction with things, with nature, with the world, with the other and with others, only thus is the person constituted as spirit. The person is both origin and member of the world, it is transcendental I incarnated, fallen into the world to transcend it. 


\section{Conclusion}

Therefore, in the transcendental constitution, over this first level of the isolated original empirical consciousness, comes the intersubjective upper level. The intersubjective world is the correlate of experience mediated by empathy. We are thus referred to the multiple units of meaning of things. Empathy plays a constituent role in "objective" experience and gives unity to the multiplicity of things. This constitution refers first to an individual consciousness and then to an intersubjective common consciousness for which a single thing can be given and identified intersubjectively as the same objective and effective thing. It is a transcendental intersubjectivity only possible thanks to the objectivity of the world.

\section{Bibliographic reference}

CRESPO, M. ¿Hay una teoría no idealista de la constitución? Revista de Filosofía, v. 65, p. 105$114,2009$.

DE OLIVEIRA. N. Husserlian theses on constitution. Manuscrito, v. XXIII, n. 2, p. 251-274, 2000. (Center of Logic, Epistemology and History of Science (CLE/UNICAMP), State University of Campinas, SP, Brazil, 2000).

HUSSERLIANA I (HUA I). Cartesianische Meditationen und Pariser Vorträge. Ed. Stephan Strasser. Den Haag: Martinus Nijhoff, 1950. Cartesian Meditations: An Introduction to Phenomenology. Tnas. Dorion Cairns. The Hague: Martinus Nijhoff, 1960 (1/43-183).

HUSSERLIANA III (HUA III). Ideen zu einer reinen Phänomenologie und phänomenologischen Philosophie. Erstes Buch: Allgemeine Einführung in die reine Phänomenologie. Ed. Karl Schuhmann. Den Haag: Martinus Nijhoff, 1976. Ideas Pertaining to a Pure Phenomenology and to a Phenomenological Philosophy. Fisrt Book. General Introduction to a Pure Phenomenology. Trans. Fred Kersten. The Hague: Martinus Nijhoff, 1982.

HUSSERLIANA IV (HUA IV). Ideen zu einer reinen Phänomenologie und phänomenologischen Philosophie. Zweites Buch: Phänomenologische Untersuchungen zur Konstitution. Ed. Marly Biemel. Den Haag: Martinus Nijhoff, 1952. Ideas Pertaining to a Pure Phenomenology and to a Phenomenological Philosophy. Second Book. Studies in the Phenomenology of Constitution. Trans. Richard Rojcewicz and André Schuwer. Dordrecht: Kluwer Academic Publishers, 1989.

LUO, Z. Motivating Empathy: The problem of bodily similarity in Husserl's theory of empathy. Husserl Studies, v. 33, n. 1, p. 45-61, 2017. 
TOURINHO, C. O problema da autoconstituição do eu transcendental na fenomenologia de Husserl: de Ideias I a Meditações cartesianas. Trans/Form/Ação, Marília, v. 39, n. 3, p. 87100, jul./set. 2016.

ZAHAVI, D. Husserl and transcendental intersubjectivity: a response to the linguistic-pragmatic critique. Trans. Elizabeth A. Benhnke. Ohio: Ohio University Press, Athens, Ohio, 2001. 